Bol. Acad. peru. leng. 63. 2018 (37-75)

\title{
LOS INICIOS DE LA PROSA CASTELLANA EN EL PERÚ
}

\section{THE BEGINNINGS OF SPANISH PROSE IN PERU}

\author{
Óscar Coello \\ Universidad Nacional Mayor de San Marcos
}

\section{Resumen:}

El presente artículo estudia los dos textos más importantes con los que se inicia la prosa castellana en el Perú: el Códex vindobunensis y el Anónimo sevillano. En un momento en que la historia era un género literario, el trabajo escruta los momentos de la ficción, así como los recursos retóricos presentes en estos dos primeros discursos artísticos. Complementariamente, resalta el caso de la fundación de Piura que precisa el Anónimo. ${ }^{1}$

\section{Abstract:}

This paper studies the two most important texts with which Spanish prose begins in Peru: Códex vindobunensis and Anónimo sevillano. At a time when history was a literary genre, this paper examines the moments of fiction, as well as the rhetorical resources present in those first two artistic

1 Este artículo es un anticipo de mi libro de igual título y de próxima aparición.

https://doi.org/10.46744/bapl.201801.002 
discourses. Complementarily, it highlights the case of the foundation of Piura specified by the Anónimo.

Palabras clave: Perú; prosa; ficción; historia; literatura.

Key words: Peru; prose; fiction; history; literature.

Fecha de recepción: $\quad$ 14/03/2018

Fecha de aceptación: $\quad 31 / 05 / 2018$

\section{El Codex vindobonensis}

El Codex Vindobonensis. Hay en la Biblioteca Nacional de Austria un legajo fáctico (el Códex Vindobonensis S. N. 1600) donde el historiador escocés William Robertson (1721-1793) encontró unas cartas extraviadas de Hernán Cortés ${ }^{2}$. Entre las dichas cartas —intercalado sin motivo aparente - se encuentra un breve texto (folios $225 \mathrm{r}^{\circ}$ a $227 \mathrm{r}^{\circ}$ ) que trata del momento preciso, junio y julio del año de $1526^{3}$, en que los capitanes Pizarro y Almagro - abatidos por no encontrar nada de lo que traían en sus sueños; y cercados por los indios que defendían ferozmente sus tierras y los ponían en «harta necesidad» ${ }^{4}$ - enviaron al piloto Bartolomé Ruiz para que explorara la costa, debajo de la línea del Ecuador. Apenas unos días después, este mítico nauta contempló por primera vez, desde el mar, los primeros pueblos del reino de los incas (sin saber aún de qué país se trataba ni quiénes eran sus habitantes). Hizo bajar a un español, por invitación de aquellos hombres, bastante diferentes de los que hasta entonces habían visto, y no pudo dejar de advertir «que venían arreados de oro», y que los jefes lucían áureas diademas. Y, después, cuando estuvo

2 Alberto M. Salas, Miguel A. Guérin y José Luis Moure. Crónicas iniciales de la conquista del Perú, pp. 37-8.

3 José Antonio del Busto Duthurburu. Pizarro, p. 514.

4 Las citas entrecomilladas del texto del Codex Vindobonensis se harán, en lo sucesivo, por la edición señalada de Alberto Salas, y otros, que viene entre las pp. 49 y 63. 
más cerca, apenas logró disimular el inquietante asombro que compartía también con ellos.

Nadie sabe a ciencia cierta quién redactó el texto Vindobonensis (Vindobona es el nombre latino de Viena, sede de la Biblioteca), si un veedor o un escribano de los que siempre iban en los barcos o si fue algún ignorado marinero de la tripulación, o el propio Bartolomé Ruiz ${ }^{5}$.

El texto fue publicado por primera vez en 1844 en la Colección de documentos inéditos para la historia de España, que hizo Martín Fernández de Navarrete y, un poco después, por don Pascual Gayangos en su edición de las cartas de Hernán Cortés ${ }^{6}$. Raúl Porras también lo publicó, en 1937, en Las relaciones primitivas de la conquista del Perú ${ }^{7}$. Porras creyó que el autor del documento era Francisco de Xerez, y le llamó la «Relación Sámano-Xerez», porque al final del manuscrito hay una nota, de distinta letra, firmada por el funcionario del Consejo Real y Supremo de las Indias, Juan de Sámano, quien la remite a algún noble de Castilla (solo dice «a Vuestra Alteza» ${ }^{8}$ ). Esta atribución (y otras supuestas autorías hechas en diversos momentos) ha sido replicada después ${ }^{9}$. Hay una edición facsimilar, de 1960, por la editorial austriaca de Graz, Akademische Druck-u. Verlagsanstalt, quien la incluyó en la sección de manuscritos de su colección Codices selecti ${ }^{10}$.

Gonzalo Fernández de Oviedo, en el siglo Xvi — por los tiempos de la rebelión de Gonzalo Pizarro ${ }^{11}$ (podría ser hacia 1544-1547) — certifica los principales sucesos que se narran en este códice. No lo menciona y,

5 Miguel A. Guérin. Crónicas iniciales de la conquista del Perú, pp. 47-48.

6 Alberto M. Salas, Miguel A. Guérin y José Luis Moure. Crónicas iniciales de la conquista del Perú, pp. 39-40.

7 Raúl Porras Barrenechea. Las relaciones primitivas de la conquista del Perú, tomo I.

8 Según observa Miguel Alberto Guérin: «alteza, a diferencia de majestad, no es tratamiento de reyes ni de emperadores». En: Salas, Op. cit., p. 38, nota 3.

$9 \quad$ Ibid., pp. 43 y ss.

10 Ibid., p. 40.

11 Gonzalo Fernández de Oviedo. Historia general y natural de Indias, pp. 121-123. 
más bien, dice que los hechos le fueron referidos — en su momento- por el propio Diego de Almagro, su amigo.

El Perú desde el mar. Cuando los buscadores de la leyenda del Reino del Perú lo vieron por primera vez, lo contemplaron desde el agua. En el relato, la espacialización enunciva ${ }^{12}$, es decir, del actante desde cuya posición espacial se miran los hechos dentro del relato, lo muestra así con claridad: «Él fue $[\ldots]$ y vio tres pueblos grandes junto a la mar».

La historia sucedió de este modo. Pizarro y Almagro solo llegaron a las riberas de un río grande al que bautizaron como el río San Juan, este queda en la actual Colombia:

[...] hallaron ahí algunas poblaciones y, por ser vistos antes que pudiesen dar en ellas, se fueron los indios con lo que tenían y algunos pueblos quemaron. Los capitanes aposentáronse en un pueblo, y los indios venieron a dar sobre ellos y les pusieron en harta necesidad, pero al fin se fueron los indios, y quedaron aposentados y procuraron de hacer la paz con ellos, pero no ha fecho.

Viendo los capitanes la poca manera que había en aquella tierra de poblar ni haberse provecho y que traían la gente muy cansada, acordaron de enviar un piloto muy bueno que tienen que se dice Bartolomé Ruiz, que fue con un navío y cierta gente la costa delante, mandándole que le siguiese dos meses, todo lo que pudiese andar. Él fue [...] y vio tres pueblos grandes junto a la mar (Salas, 1987: 54-55).

Bartolomé Ruiz, el piloto descubridor del Reino del Perú. Bartolomé Ruiz comienza a bordear la costa con su frágil navío, avanza por lo que ahora es la república del Ecuador y allí, por la zona de la actual Esmeraldas, arriba a una bahía a la que bautiza con el nombre de otro evangelista, San Mateo. Muy cerca, descubre tres pueblos donde las gentes se vestían con notorios atavíos de oro. En realidad, el descubrimiento fue mutuo; los regnícolas también se apresuraron en querer saber de ellos: «Él fue, aunque

12 Joseph Courtés. Análisis semiótico del discurso, p. 386. 
con mucho trabajo, y halló una bahía muy buena que puso nombre de Sant Mateo, y allí vio tres pueblos grandes junto a la mar, y salieron algunos indios a él, que venían arreados de oro y tres principales puestas unas diademas, y dijeron al piloto que fuese con ellos [...]» (Salas, 1987: 55).

Ese territorio era ya parte del país de los incas. Los expedicionarios no lo sabían, pero estaban ya en los dominios inmensos del inca Huayna Cápac, en lo que era la parte del reino de Quito. Los indios los hicieron bajar del barco. Pero los navegantes solo hicieron descender a un español de apellido Bocanegra, el cual terminó de darse cuenta de que habían arribado al pueblo soñado donde las gentes discurrían naturalmente por sus calles adornadas ricamente con sus arreos de oro; $y$, cuando hubo de regresarse, le regalaron un poco del áureo metal para que se lo llevara de recuerdo: «[...] dioles un hombre que se dice de Bocanegra, y estuvo allá dos días, y violes andar arreados de oro, y diéronle un poco de oro por fundir» (íd.).

En la otra mitad del mundo. Vuelto el español «que se dice de Bocanegra» al navío, «acompañado de los indios que le habían llevado y de otros muchos», Bartolomé Ruiz siguió avanzando por la costa y se dio cuenta de que toda era «tierra llana y de muchas poblaciones». Cuando traspuso la línea equinoccial o línea ecuatorial advirtió que había desaparecido la estrella polar, que le servía de norte ${ }^{13}$. Bartolomé Ruiz bajó hasta la costa de Tumbes (la ciudad actual está situada a $3^{\circ} 34^{\prime} 0$ 'S), donde se le cumplió el plazo de dos meses y tuvo que retornar a su base del río San Juan: «[...] hallaron ser que estaban daquella parte de la línea quinocial, tres grados y medio, perdido el Norte. Dallí, porque se les acababa el término, dieron vuelta» (Salas, 1987: 55-56).

El ENCUENTRO CON LA BALSA DE LOS INCAS. Regresaron reconociendo la tierra nueva siempre desde el navío; de vez en cuando bajaban a proveerse de agua y para «tomar posesión». En eso fue que se toparon en plena mar con una balsa de comerciantes (incas, pero no sabían aún quiénes eran), que navegaban haciendo «rescates», es decir, compraban y vendían diversos

13 El manuscrito no lo dice pero, sin duda, en este nuevo cielo admiraron ya la clarísima Cruz del Sur.

Bol. Acad. peru. leng. 63(63), 2018 / e-ISSN: 2708-2644 
bienes. Los dos barcos en los que salieron los españoles de Panamá eran de cuarenta y de setenta toneles, respectivamente, dice al comienzo este mismo códice; la balsa de los navegantes desconocidos era de unos treinta toneles, estaba hecha de unas cañas, como gruesos palos flotantes, amarradas con juncos fuertes, que formaban el piso. En verdad, tenía dos pisos de estas cañas. Y también tenían mástiles altos de fina madera, con cruces o antenas, que sostenían las grandes velas de algodón, que eran «del mismo talle e manera que los nuestros navíos» (Salas, 1987: 56); así dice el navegante español que escribe el texto inaugural de la prosa castellana en el Perú. Llevaban sogas de junco como jarcia para arriar las velas, y usaban una piedra enorme como ancla. En el piso alto iban las mercaderías, y por ellas se dieron cuenta del grado de desarrollo del país de donde venían estos hombres. Es más, escogieron a tres de ellos, tripulantes de la balsa incógnita, y les hicieron buen tratamiento para que aprendieran el idioma español y sirvieran de traductores o lenguas o farautes:

En esta tierra llana, muy poblada, dieron algunas calas para tomar posesión e proveerse de agoa. Tomaron un navío en que venían hasta veinte hombres, en que se echaron al agoa los once dellos y los otros echolos así mismo en tierra para que se fuesen. Y estos tres que quedaron para lenguas, hízoles muy buen tratamiento y trújolos consigo.

Este navío que digo que tomó, tenía parecer de cabida de hasta treinta toneles, era hecho por el plan e quilla de unas cañas tan gruesas como postes, ligadas con sogas de uno que dicen henequén, que es como cáñamo, y los altos de otras cañas más delgadas, ligadas con las dichas sogas, a do venían sus personas y la mercaduría en enjuto, porque lo bajo se bañaba. Traíe sus másteles y antenas de muy fina madera y velas de algodón del mismo talle e manera que los nuestros navíos, y muy buena jarcia del dicho henequén, que digo que es como cáñamo, e unas potalas por anclas, a manera de muela de barbero (Salas, 1987: 56-57).

Las PRimicias del reino encontrado. Por los objetos con los que vieron que comerciaban, pronto se dieron cuenta del avance cultural del país que habían hallado. Las gentes eran ricas y vestían con oro, pero las muestras de su comercio exhibían —además — la delicada textilería (inca) en algodón y en 
lana de vicuña o alpaca «todo lo más dello muy labrado de labores muy ricas, de colores de graña y carmesí y azul y amarillo y de todas otras colores». Les llama la atención una balanza o «romana» para pesar el oro de sus transacciones, y unas conchas marinas que ya habían comprado, "que traían así el navío cargado dellas». Eran estos los bellos spondylus o «mullo» del Ecuador, que importaban los incas del Perú para sus ofrendas ceremoniales.

Traían muchas piezas de plata y de oro para arreo de sus personas, para hacer rescate con aquellas con quien iban a contratar, en que intervenían coronas y diademas y cintos y puñetes y armaduras como piernas y petos y tenazuelas y cascabeles y sartas y mazos de cuentas y rosecleres y espejos goarnecidos de la dicha plata y tazas y otras vasijas para beber.

Traían mantas de lana y algodón, y camisas y aljulas y alcaceres y alaremes y otras muchas ropas, todo lo más dello muy labrado de labores muy ricas, de colores de graña y carmesí y azul y amarillo y de todas otras colores, de diversas maneras de labores e figuras de aves y animales y pescados y arboledas; y traían unos pesos chiquitos de pesar oro, como hechura de romana, y otras muchas otras cosas. En algunas sartas de cuentas venían algunas piedras pequeñas de esmeraldas y cazadonias y otras piedras y pedazos de cristal y anime. Todo esto traían para rescatar por unas conchas de pescado, de que ellos hacen cuentas coloradas como corales, y blancas, que traían así el navío cargado dellas (Salas, 1987: 57-58).

LOS CAPITANES QUIEREN CONOCER TAMBIÉN EL PÓRTICO DEL REINO DEL Oro. Bartolomé Ruiz regresó a su base — al cabo de los dos meses establecidos - en la desembocadura del río San Juan, en Colombia, donde lo esperaban los capitanes Pizarro y Almagro. El piloto mayor, Ruiz, les comunicó «la buena nueva de la buena y llana tierra que había hallado». Todos se alzaron presurosos a conocerla, unos por tierra y otros por mar, en rutas paralelas. Pasaron la bahía de San Mateo y avanzaron hasta Tacámez, en la actual república del Ecuador. Los que iban por mar, de pronto se vieron rodeados de catorce canoas grandes con gente vestida de oro y plata (llevaban trajes como armaduras de oro y plata), y la canoa principal estaba engalanada con un busto grande de oro como seña o mascarón de 
proa. Las ligeras naves incas circundaron los dos pequeños navíos españoles y luego se fueron por unos bajos por donde no las podían seguir los barcos españoles. Los capitanes que estaban en tierra con la otra gente no vieron nada de esto:

[...] fuéronse por la costa adelante a dar en otro pueblo que estaba cuatro legoas de allí, muy grande, que se dice Tacámez; yendo los capitanes y gente por tierra, y los maestros marineros con los navíos por mar, salieron a los dichos navíos cuatorce canoas grandes con muchos indios, todos armados con oro y plata, y traíen en la una canoa o en estandarte y encima dél un bolto de un mucho de oro, y dieron una vuelta a los navíos para visitarlos, en manera que no los pudiese enojar, e así dieron vuelta hacia su pueblo, y los navíos no les pudieron tomar porque se metieron en los bajos, juncto a la tierra, y los capitanes y gente que venían por tierra no vieron nada desto (Salas, 1987: 59-60).

¿QuiÉNES SON ESTAS GENTES? El códice ensaya algunas primeras explicaciones acerca del reino descubierto. Se dieron cuenta rápidamente de que eran muy inteligentes. El manuscrito deja bien claro este hecho: eran gente de mucha cultura o "policía», como se decía en el castellano de la época: «Aquellos tres indios que digo que se tomaron en el navío, que se llevaron a los Capitanes, tomaron nuestra lengua muy bien. Parece que ellos eran de una tierra y pueblo que se dice Çalangane; es gente en aquella tierra de más calidad y manera que indios, porque ellos son de mejor gesto y color, y muy entendidos y tienen una habla como arábigo» (Salas, 1987: 61).

También ensaya una breve descripción del país que han encontrado. Habla de sus animales (nombra «ovejas» a los auquénidos del Nuevo Mundo, es decir, a las llamas, alpacas, guanacos, etc.). Los expedicionarios no solo han visto la textilería, sino que se habían fijado también en su habilidad agrícola y minera, en las herramientas que usaban, en el trazo de sus calles y ciudades, en su buen gobierno o «policía»:

Allí hay muchas ovejas y puercos y gatos y perros y otras animalías, y ánsares y palomas; y allí hacen las mantas que arriba digo de lana y algodón, y las labores y las cuentas y piezas de plata y oro, y es gente de 
mucha polecía, segund lo que parece. Tienen muchas herramientas de cobre e otras metales con que labran sus heredades y sacan oro y hacen todas maneras de granjería. Tienen los pueblos muy bien trazados de sus calles, tienen muchos géneros de fortalezas y tienen mucha orden y justicia entre sí (Salas, 1987: 61-62).

No lo sabían aún, pero habían llegado al inmenso país de los incas, al que después acabarían por identificar y nombrar como el país que buscaban, es decir, el de la leyenda del reino dorado del Perú ${ }^{14}$. El movedizo país «del oro y las piedras preciosas» ${ }^{15}$ que habían venido persiguiendo, desde 1513 , aquella vez cuando contemplaron por primera vez el infinito de la mar del Sur.

LOS COMIENZOS DE LA FICCIÓN. Esta es una literatura que brota de la realidad, sin duda, pero no se queda en ella. Bien pronto, la pluma del escritor se desliza por los inadvertidos pasadizos de la ficción. Aquí, en este mismo relato, da cuenta de que los navegantes han visto mujeres blancas y bien ataviadas; y cuenta también que en una isla hay una capilla con una imagen —que reproduce evidentemente nuestra efigie de la Virgen María con el niño Dios en sus brazos - a la que los naturales rinden culto y le solicitan milagros, y a la que, por lo demás, llaman María Mexía:

Las mujeres son muy blancas y bien ataviadas, y todas por la mayor parte labranderas. Hay una isla en la mar, junto a los pueblos, donde tienen una casa de oración, hecha a manera de tienda de campo, toldada de muy ricas mantas labradas, a do tienen una imagen de una mujer con un niño en los brazos, que tiene por nombre María Mexía. Cuando alguno tiene alguna enfermedad en algund miembro, hácele un miembro de plata o de oro y ofrécesela; ahí sacrefican delante de la imagen ciertas ovejas en cierto tiempo (Salas, 1987: 62).

Y así termina el texto. El escritor descorre apenas las cortinas de la maravilla, casi solo susurra el secreto de esta tierra nueva «llana y buena

14 Óscar Coello. «Los comentarios del Inca y la leyenda del Perú». En: Boletín de la Academia Peruana de la Lengua, pp. 37-41.

15 Ynca Garcilaso de la Vega. Commentarios reales, fol. 4v. ${ }^{\circ}$ 
tierra que habían hallado». No sabe — no lo podían saber todavíacuáles eran las reales dimensiones de lo que acababan de encontrar.

LA PROMESA DEL RETORNo. Solo se detuvieron a la entrada del rico país descubierto. También se dieron cuenta los curtidos expedicionarios de que no era posible que ellos solos se atreviesen a nada ${ }^{16}$. Pero ya estaba decidido el retorno; tenían que regresar a la tierra que apenas habían tocado. Fue entonces que se recogieron en la isla del Gallo, en el extremo sur de la actual Colombia, para reorganizarse y meditar cómo proseguir después la aventura. En este momento, no deja de llamar la atención el embrague espacial ${ }^{17}$ del enunciador, que deja ver el lugar desde donde escribe el texto («veniese con un navío a Panamá»). Es de los que se regresan con Almagro a Panamá en busca de refuerzos:

[...] e viendo los capitanes la mucha multitud de indios que había, porque era pueblo de mill e quinientas casas y estaban otros pueblos junto, de que se recogían más gente, y ellos no eran de ochenta hombres arriba, sin los de los navíos, para poder pelear, parecioles de retirarse y así, disimuladamente, se salieron y embarcaron y volvieron a una isla que está veinte e cinco legoas atrás, con acuerdo que el capitán Francisco Pizarro se quedase allí con los navíos e gente, y el capitán Almagro veniese con un navío a Panamá por cient hombres de socorro e algunos caballos e pertrechos para tornar a dar en el dicho pueblo (Salas, 1987: 62).

Prosa del Prerrenacimiento. El anónimo escritor pertenece a una época literaria que se ha denominado el Prerrenacimiento ${ }^{18}$. Estos relatos, a diferencia de aquellos de argumento bien cerrado (exposición, nudo, desenlace) que se produjeron en el Renacimiento, mantienen aún la visión panorámica del mundo, propia de las narraciones medievales ${ }^{19}$. El anónimo escritor abre el relato — sin más antecedentes — con la partida súbita de los capitanes Pizarro y Almagro en busca de «una provincia que se dice el Perú, que

16 Sabemos que la noticia de la tierra nueva fue guardada con cierta discreción por todos; había que hablar directamente con el emperador Carlos V; Pizarro viajaría en 1529 a buscarlo.

17 Joseph Courtés. Análisis semiótico del discurso, p. 371.

18 María Rosa Lida de Malkiel. Juan de Mena, poeta del Prerrenacimiento español, p. 9.

19 Ibid., pp. 15, 31 y 159. 
es en la misma costa de Tierra Firme, en la parte del mar del Sur, de donde es la ciudad de Panamá, hacia el levante, partieron en el año de veinte e cinco» (Salas, 1987: 50). El relato pasa rápidamente los sucesos hasta el río San Juan, que es donde empieza a contar la aventura de Bartolomé Ruiz, el protagonista principal de este breve texto. La visión del reino descubierto es también rápida, demasiado rápida. Pero, de pronto, se detiene en un punto: el encuentro con la balsa extraña. Ahí sí se solaza con la visión. El relato se vuelve minucioso, detallado. Como que el valor del reino del oro se conjetura a partir de la balsa desconocida encontrada en alta mar. Y luego da cuenta sucintamente del retorno a su base, con la buena noticia para los capitanes, que quisieron certificar el hallazgo inmediatamente. Los capitanes van por tierra y, al asomarse, bien alcanzan a darse cuenta de que ellos solos no podrían nada, porque se trata de un país vasto; por lo que «parecioles de retirarse y, así, disimuladamente se salieron y embarcaron». Entre tanto, los que iban por la mar viven un suceso definitivamente maravilloso: son rodeados por muchas balsas de hombres «todos armados de oro y plata», que se evaden. Y, finalmente, narra en unos cuantos trazos el regreso a la tierra firme de Panamá. Pero, antes de suspender el relato abruptamente, repasa nuevamente en la memoria la imagen de la gente de la balsa inca y ensaya algún pensamiento sobre su admirable cultura y aquella «lengua como arábigo». Ahí es donde entreabre las puertas de la maravilla cuando cuenta la visión de la imagen mariana en la isla perdida de la mar del Sur: «[...] ahí sacrifican delante de la imagen ciertas ovejas en cierto tiempo». Y, del mismo modo como comenzó, súbitamente, se detiene del todo. Deja todo en suspenso y termina de contar. Estamos así ante el relato abierto del arte prerrenacentista. Y como que nos queda la sensación, al finalizar el texto, de haber visto un vuelo de pájaro sin comienzo ni final. $\mathrm{O}$, dicho de modo directo, la imagen perdurable que nos queda de este relato marino es el de una balsa furtiva que exhibe las relucientes primicias del reino encontrado. Y es desde aquí, desde la balsa, desde donde los lectores debemos empezar a imaginar todo lo demás.

Otras MARCAS DE LA PROSA PRERRENACENTISTA: LA AMPLIFICATIO RERUM. Es posible descubrir en este texto recursos propios de este momento literario. Por ejemplo, esa tendencia a acumular las cosas y los objetos del mundo representado con el propósito de amplificar la sensación 
visual de la escena artística (la amplificatio rerum), tal como se aprecia en algunos ejemplos ya propuestos. $\mathrm{O}$ en este otro texto: «[...] y tienen una lengua como arábigo, y a lo que parece ellos [tienen] subjeción sobre los indios que digo de Tacámez, y de la bahía de San Mateos y de Nancabes y de Tovirisimi y Conilope y Pasagayos y Tolona y Quisimos y Coaque y Tonconses y Ajan y Pasaos y Pitangua y Caraz, Lobes, Xamarejos, Camej, Amotopej, Docoa, todos pueblos de la dicha tierra llana $[\ldots] »($ Salas, 1987: 61).

LA AMPLIFICATIO VERBORUM. Es de destacar en este tipo de prosa el uso del polisíndeton y del asíndeton - como es de ver al comienzo y al final del párrafo arriba citado- por la habilidad con que el narrador los ha combinado. En otro momento, el polisíndeton campea en esta prosa breve para lograr el referido efecto de las acumulaciones, en apenas unos cuantos trazos:

[...] partieron en el año de veinte e cinco con dos navíos de cuarenta y setenta toneles, y un bergantín pequeño, y hasta cient y cincuenta hombres compañeros de tierra, y sus maestres y marineros, que discurriendo por la dicha costa hasta dar en la dicha provincia, y hallaron algunos pueblos junto a la mar, pequeños, y con algunos dellos asentaban sus paces y pasaban de largo (Salas, 1987: 50).

Una anáfora artísticamente bien disimulada la podemos ver en el párrafo arriba citado donde narra las primicias encontradas en el navío inca: «Traían muchas piezas de plata y de oro [...] Traían mantas de lana y de algodón [...] traían unos pesos chiquitos de pesar oro [...]. Todo esto traían para rescatar por unas conchas de pescado» (Salas, 1987: 57; énfasis nuestro).

\section{La conquista del Perú (el Anónimo sevillano), abril de 1534}

El Anónimo sevillano. En abril de 1534, en la imprenta de Bartolomé Pérez, en Sevilla, se publicó un breve libro (apenas ocho folios), que lucía como carátula un grabado del inca Atahualpa en su litera sosteniendo en la mano el texto sagrado que le había alcanzado el P. Vicente Valverde. 
https://doi.org/10.46744/bapl.201801.002

Esa misma imagen de la xilografía de la tapa se utilizaría tres meses después para publicar la Verdadera relación de la conquista del Perú, escrita por el secretario de Pizarro Francisco de Xerez. Y esta se tituló así («Verdadera»), porque el anónimo escritor — que se le había anticipadohabía contado los hechos fascinantes del descubrimiento a su desatado modo, bajo un título que lo decía todo y en suma: La conquista del Perú.

Hoy se conservan unos poquísimos ejemplares de este anónimo incunable ${ }^{20}$. Pero hay, desde 1929, una magnífica edición facsimilar reeditada y transcrita varias veces ${ }^{21}$.

Se han tejido muchas conjeturas acerca del posible autor. La más conocida es la del maestro Raúl Porras, que atribuye el texto al capitán Cristóbal de Mena. Sin embargo, esta atribución no se ha librado de recibir fuertes réplicas ${ }^{22}$.

La noticia de la CONQuista del país Del oro. El texto daba cuenta de cómo los expedicionarios guiados por el «muy magnífico y valeroso caballero, el capitán Francisco Pizarro, gobernador y adelantado de la Nueva Castilla, y de su hermano Hernando Pizarro y de sus animosos capitanes y fieles y esforzados compañeros que con él se hallaron ${ }^{23}$ » habían capturado el Perú del oro (cuyo nombre había sido fijado de forma oficial en las Capitulaciones de Toledo, de 1529, entre Pizarro y la Corona, como La Nueva Castilla ${ }^{24}$, aquella vez que llevaron la noticia al rey del país descubierto por el intrépido navegante Bartolomé Ruiz, al que distin-

20 Sabemos que hay uno en la New York Public Library y otro en el British Museum.

21 Joseph H. Sinclair. The Conquest of Peru as Recorded by a Member of the Pizarro Expedition. Reproduced from the copy of the Seville edition of 1534 in the New York Public Library with a translation and annotations by [...].

22 Miguel Alberto Guérin. «Introducción». En: Alberto M. Salas y otros. Crónicas iniciales de la conquista del Perú, pp. 67-88.

23 Las citas entrecomilladas del texto del Anónimo sevillano se harán, en lo sucesivo, por la edición señalada de Alberto Salas, y otros, que viene entre las pp. 89 y 118.

24 Como sabemos, Perú fue el nombre castellano popular que le dio la hueste descubridora. Finalmente, fue este, el nombre de la leyenda, el que prevaleció al remoto y postizo nombre oficial (cf.: Óscar Coello. «Los comentarios del Inca y la leyenda del Perú». En: Boletín de la Academia Peruana de la Lengua, p. 40. 
guieron - ahí mismo, 26 de julio ${ }^{25}$ — con el título de Piloto Mayor de la Mar del Sur).

LA ENTRADA EN EL TERRITORIO DESCONOCIDO. El anónimo narrador lo cuenta todo; en primer lugar, confirma que se trataba de un país de alto desarrollo (así lo había asegurado, desde 1526, el descubridor Bartolomé Ruiz). Cuenta rápidamente cómo fue el avance de la pequeña hueste hispana en la captura definitiva del país del delirio. Salieron de Panamá en febrero de 1531 «doscientos y cincuenta hombres, los ochenta de caballo»; pero en el camino se quedaron muchos: muertos, enfermos o desanimados. Antes de partir a Cajamarca en pos del inca ya eran «todos ciento y cincuenta, en que irían cuasi sesenta de caballo». En cuanto cruzaron los límites del país desconocido, el señor de estas tierras, el «cacique» Atahualpa, los mandó a espiar:

Cuando Atabálipa supo que iban los cristianos, envío un capitán a espiar qué gente éramos. Este capitán vino a nuestro real disfrazado como indio de baja suerte, y no osó con toda su gente dar en nosotros, mas luego se volvió a hacer relación a su Señor, y le dijo que le diese más gente y que volvería a dar en los cristianos. El Cacique le respondió (según después nos dijo) que más a su salvo tomaría a los cristianos cuando ellos llegasen adonde él estaba (Salas, 1987: 90-91).

La fundación del Perú castellano. Al llegar, los acogió una población de indios amigos llamada Tangarará, cerca de lo que hoy es Sullana; allí iniciaron el mestizaje. Fundaron un pueblo español y, para bautizarlo, enlazaron el nombre indígena tallán con el nombre del arcángel que, en su fe, los venía cuidando en la aventura, es decir, San Miguel de Tangarará: «fuimos a un pueblo llamado Tangarará, adonde hicimos una población que llamamos Sant Miguel»(Salas, 1987: 90).

Encontraron un País en Guerra. Allí, en San Miguel de Tangarará, se enteraron «de un gran señor llamado Atabálipa, el cual tenía guerra con su hermano menor llamado el Cozco» ${ }^{26}$. La guerra era crudelísima; el relato

25 Raúl Porras Barrenechea. Cedulario del Perú (siglos XVI, XVII y XVIII), pp. 21 y 42.

26 El narrador llama Cozco a quien después, nosotros, conoceríamos como Huáscar. 
describe la devastación. En el camino que emprendieron - despuéshacia Cajamarca en pos de Atabálipa, hallaron un pueblo llamado Caxas: «Este pueblo estaba muy destruido de la guerra que le había dado Atabalipa; por los cerros había muchos indios colgados porque no se le habían querido dar, porque todos estos pueblos estaban primero por el Cozco, y le tenían por señor, y le pagaban tributo» (Salas, 1987: 93).

La CONDICIÓn DE LA MUjer. En ese mismo pueblo, Caxas, se dan cuenta de varias cosas: el grado de desarrollo del país en el que estaban y de su avanzada organización. Pero también se dan cuenta de su condición de pueblo cruelmente avasallado por Atahualpa. También, se dan cuenta del rol de la mujer como sierva muda: «Llegaron al pueblo que era grande, y en unas casas muy altas hallaron mucho maíz y calzado; otras estaban llenas de lana y más de quinientas mujeres que no hacían otra cosa sino ropas y vino de maíz para la gente de guerra. En aquellas casas había mucho de aquel vino ${ }^{27} »$ (Salas, 1987: 92-93). Cuando los españoles prosiguen su avance en pos de Atahualpa, el cacique de aquel pueblo «abrió una casa de aquellas, que estaba cerrada y puesta guarda por Atabálipa, y sacó della cuatro o cinco mujeres y diolas al Capitán, para que sirviesen a los cristianos en guisar de comer por los caminos» (Salas, 1987: 93).

LAS ALIANZAS CON LOS PUEBlos VENCIDOS. Caxas es una buena muestra de cómo los españoles son acogidos como amigos y aliados por los pueblos vencidos por Atahualpa. Al llegar, Hernando de Soto, quien iba al frente de la avanzada cristiana, pide hablar con el cacique del lugar: «El Capitán envió a llamar al cacique de aquel pueblo, y luego vino, quejándose mucho de Atabálipa, de cómo los había destruido y muerto mucha gente, que de diez o doce mil indios que tenía, no le había dejado más de tres mil $[\ldots] »$ (Salas, 1987: 93). Hernando de Soto les ofreció su amistad: «El señor Capitán les dijo que estuviesen en paz con los cristianos y que fuesen vasallos del Emperador, y que no tuviesen miedo de Atabálipa. El cacique se holgó mucho [...]» (Salas, 1987: 93).

27 En realidad, se refiere a la chicha. 
El texto da otros testimonios de cómo los españoles habían venido haciendo alianzas a lo largo del camino con muchos de estos pueblos enemigos de Atahualpa. Inclusive, hay un caso en el que se muestra que la alianza no solo era de paternal protección militar hispana, sino que los indígenas asumieron una activa participación colaboracionista para enfrentar a Atahualpa y abolir su tiranía: fueron parte de la diplomacia hispana para desafiar al Estado inca. Jefes indios de la zona de Tangarará - es decir, los tallanes - aparecen como altivos mensajeros o embajadores de Pizarro, y lo tenían al tanto de las tretas empleadas por Atabálipa contra sus enemigos: el envenenamiento, el contagio u otros macabros procedimientos:

[...] era este indio cacique de los pueblos en los cuales los cristianos estaban repartidos, y eran grandes amigos de los cristianos. Este cacique fue al real de Atabálipa y sus guardas no le dejaron llegar allá, antes le preguntaron que de dónde venía el mensajero de los diablos que por tanta tierra habían venido y no había quién los matase. El cacique le dijo que le dejasen ir a hablar con el Atabálipa, porque cuando algún mensajero iba a los cristianos, ellos le hacían mucha honra; y ellos no le dejaron pasar adelante. Aquella noche [el cacique mensajero] vino a dormir donde el Gobernador había llegado con su gente, y había avisado al Gobernador que ninguna cosa de comer que el Atabálipa enviase, no la comiésemos, y así fue hecho, que toda la vianda que el Atabálipa envió fue dada a los indios que llevaban las cargas (Salas, 1987: 97).

Las amenazas de Atahualpa. El poder militar de Atahualpa no solo le permitía dejar correr el tiempo y esperar el momento adecuado para acabar con los españoles, sino que cuando se adentraron en la cordillera de los Andes, envió un guerrero a Caxas para intimidarlos con una claridad didáctica impensada. Les iba a arrancar el pellejo:

Estando en esto, vino un capitán de Atabálipa. El cacique [de Caxas] hubo gran temor y se levantó en pie, que no osó estar asentado delante dél; mas el señor Hernando de Soto lo hizo asentar cerca de sí. Este capitán traía un presente para los cristianos de parte de Atabálipa. El presente era todo de patos desollados, que significaba que así habían de desollar a los cris- 
tianos. Y, más, trujo dos fortalezas muy fuertes hechas de barro, diciendo que otras había adelante como aquellas [...] (Salas, 1987: 93-94).

Los españoles no se amilanaron y, más bien, devolvieron el presente con cosas de España. Pizarro le dio al guerrero de Atahualpa «una camisa muy rica y dos copas de vidrio para que las llevase a su señor y le dijese que él era su amigo» (Salas, 1987: 94).

EN la RUTA DEL QHAPAP $\tilde{N} A N$. El texto solo describe fugazmente el soledoso camino inca por donde avanzaban. No sabían que estaban caminando por el soberbio Qhapap Nan (en quechua, «el camino real») que entrecruzaba todo el país desconocido, y que es el que les permite adentrarse fácilmente en pos de Atahualpa: «De allí a dos días se partió el Gobernador [Pizarro] para ir a verse con Atabálipa, y hallaba por el camino destruidos los más de los pueblos y los caciques ausentados, que todos estaban con su señor. Yendo por aquel camino, que era la mayor parte tapiado de las dos partes y árboles que hacían sombra, de dos en dos leguas, hallábamos aposento» (Salas, 1987: 94).

TORTURAS MEDIEVALES. Los españoles no solo obtienen información apreciable de los indios amigos. Llegado el caso, también someten a graves torturas medievales a los indios desconocidos que encuentran en el camino. En efecto, cuando están cerca de Cajamarca, un capitán (no dice si fue Hernando de Soto o Hernando Pizarro) ablandó con fuego - y otras cosas que no dice- a dos indios para que delataran la posición de Atahualpa:

Antes de llegar al pueblo tomamos dos indios por saber nuevas del cacique Atabálipa; el Capitán los mandó atar a dos palos, porque tuviesen temor. El uno dijo que no sabía de Atabálipa; mas que el otro [día] — había pocos días- había dejado con el Atabálipa al cacique señor de aquel pueblo. Del otro supimos que Atabálipa estaba en el llano de Caxamalca con mucha gente, esperando a los cristianos, y que muchos indios guardaban dos malos pasos que había en la sierra, y que tenían por bandera la camisa que el Gobernador había enviado al cacique Atabálipa, y que él no sabía otra cosa más de lo dicho; y con fuego ni con otra cosa nunca dijo más desto (Salas, 1987: 95). 
En este fragmento hay dos imágenes que podríamos contemplar. Primera: la actitud beligerante de la gente de Atahualpa, que enarbola como «bandera la camisa» española que había enviado Pizarro como respuesta a la amenaza de los patos desollados. Segunda: que los españoles, al momento de realizar estas torturas — de quemar a los indios con fuego-, cuentan con la complicidad (o, al menos, la pasividad y el silencio) de los traductores, es decir, de los indios amigos, adversarios jurados de Atahualpa.

A vistas del real de Atahualpa. Con la información de los indios torturados prosiguen el avance hacia Cajamarca y, en efecto, desde los cerros contemplan en lontananza el inmenso campamento —el real- de Atahualpa: "Antes de hora de vísperas llegamos a vista del pueblo, que es muy grande y hallamos muchos pastores y $\operatorname{carneros}^{28}$ del real de Atabálipa, y vimos abajo del pueblo, cerca de una legua, una casa cercada de árboles; alrededor de aquella casa, a cada parte, estaba cubierto de toldos blancos más de media legua; allí era el real donde el Atabálipa nos estaba esperando en el campo» (Salas, 1987: 97).

La Diplomacia de los Regalos. Antes de la entrada a Cajamarca, los españoles reciben varios presentes de Atahualpa, que ellos corresponden con regalos de España. Curiosamente, los presentes de Atahualpa siempre son de alimentos y, como hemos visto, los indios amigos tenían advertido a Pizarro que no los ingirieran: «Aquella noche vinieron dos indios con diez o doce ovejas, por mandado del Atabálipa y las dieron al Gobernador. Él les dio muchas cosas y los envió. En aquella sierra tardamos cinco días, y una jornada antes que allegásemos al real del Atabálipa, vino de su parte un mensajero, y trujo en presente muchas ovejas cocidas y pan de maíz y cántaros con chicha» (Salas, 1987: 96).

Las mujeres de Atahualpa. Cuando se produce el primer encuentro con Atahualpa, en su casa (actualmente a estos lugares se le conocen como «Los baños del Inca», en Cajamarca, y son un hermoso recinto de

28 Auquénidos americanos: llamas, alpacas, vicuñas, guanacos. 
aguas termales) al escritor le llama poderosamente la atención el séquito de mujeres que están a su alrededor: «[...] y llegaron donde estaba el Cacique, y halláronlo que estaba asentado a la puerta de su casa, con muchas mujeres alderredor dél, que ningún indio osaba estar cerca dél» (Salas, 1987: 98). Más adelante, cuando De Soto y Hernando Pizarro se entrevistan con Atahualpa, da detalles del exquisito servicio que le prestaban: «El Cacique envió dos indias, y trujeron dos copones grandes de oro para beber, y ellos, por contentarle hicieron que bebía, pero no bebieron, y despidiéronse dél» (Salas, 1987: 99).

Las cabriolas de Hernando de Soto. Hernando de Soto — quien años después emprendería la búsqueda de la Fuente de la Juventud, por lo que hoy es La Florida (USA)—, terminada la entrevista con Atahualpa, pica espuelas y asusta con el caballo a un escuadrón de lanceros de la guardia de Atahualpa. Cuando se fueron los españoles, Atahualpa hizo matar a todos los indios que se asustaron, y a sus mujeres e hijos:

Hernando de Soto arremetió el caballo muchas veces por junto a un escuadrón de piqueros, y ellos se retrujeron un paso atrás. Después de idos los cristianos de allí, ellos pagaron bien lo que se retrujeron, que a ellos y a sus mujeres e hijos mandó el Cacique cortar las cabezas, diciendo que adelante habían ellos de ir, que no volver atrás, y que a todos los que volviesen atrás había de mandar hacer otro tanto (Salas, 1987: 99).

En realidad, De Soto habría intentado asustar también a Atahualpa, pero este ni se inmutó cuando el caballo le resopló en la misma mascaypacha ${ }^{29}$ :

Y llegó Hernando de Soto con el caballo sobre él, y él se estuvo quedo, sin hacer mudanza, y llegó tan cerca, que una borla que el cacique tenía, tocada, puesta en la frente, le aventaba el caballo con las narices; y el Cacique nunca se mudó. El capitán Hernando de Soto sacó un anillo del dedo y se lo dio, en señal de paz y amor, de parte de los cristianos; él lo tomó con muy poca estima (Salas, 1987: 98-99).

29 El tocado de plumas iridiscentes, a modo de corona real, que lucía Atahualpa. 
Esplendor y poderío de Atahualpa. Después de la visita de los capitanes De Soto y Hernando Pizarro, queda concertado el encuentro de Atahualpa y el gobernador Francisco Pizarro en la ciudad de Cajamarca, a unos seis kilómetros de donde se encontraba el real del soberano indio. Dijeron los capitanes al gobernador que tendría como cuarenta mil guerreros, cuando tal vez eran ochenta mil: "Los capitanes volvieron al señor Gobernador y le dijeron todo lo que habían pasado con el Cacique, y que les parecía que la gente que tenía serían cuarenta mil hombres de pelea; y esto dijéronlo por esforzar a la gente, que más había de ochenta mil» (Salas, 1987: 100).

El ejÉrcito Dorado. La entrada de Atahualpa a la plaza de Cajamarca fue espectacular. Se trataba de un resplandeciente ejército de guerreros, todos ellos ceñidos con coronas de oro y de plata:

A hora de mediodía comenzó Atabálipa a partir de su real con tanta gente que todos los campos venían llenos, y todos estos indios traían unas patenas grandes de oro y plata como coronas en las cabezas; parecía que venían todos con sus arneses vestidos. [...] El Cacique traía delante de sí, vestidos de una librea, cuatrocientos indios, los cuales venían quitando delante dél todas las piedras y pajas que hallaban por el camino por donde llevaban al Cacique en las andas (Salas, 1987: 100-101).

La captura de Atahualpa. Lo cierto es que, en la misma mañana, mediante mensajeros, se había pactado una entrevista con hombres armados: «Otro día por la mañana, no hacían sino ir y venir mensajeros al real de Atabálipa, y una vez decía que había de venir con sus armas, otra vez decía que había de venir sin ellas. El Gobernador le envío a decir que viniese como quisiese, que los hombres bien parecían con sus armas» (Salas, 1987: 100).

Al atardecer, para el momento del encuentro, Pizarro había distribuido (y escondido) su gente en cuatro casas grandes: tres al mando de Hernando Pizarro, de De Soto y de Benalcázar, con unos quince caballos dentro cada uno; y otra donde esperaba el propio Francisco Pizarro con tres caballos y unos veinticinco hombres de 
a pie. El artillero Pedro de Candia con «ocho o nueve escopeteros, y cuatro tiros de artillería» se subió a una fortaleza que había en el centro de la plaza.

Cuando apareció Atahualpa no vio a nadie y dijo: «¿Dónde están estos cristianos? Ya están todos escondidos, que no aparece ninguno». Y un jefe indio comenzó a llamar a su gente para que trajeran las lanzas, probablemente, a fin de comenzar la cacería de españoles: «Y un capitán, con una pica muy alta con una bandera, hizo una seña que viniesen las armas». Fue entonces que salió el P. Vicente Valverde «con una cruz en la mano» para hablarle a Atahualpa de las cosas de Dios. La única respuesta que tuvo fue «que él no pasaría más adelante hasta que le volviesen los cristianos todo lo que le habían tomado en toda la tierra». Y, como viera al P. Valverde con un libro en la mano, se lo pidió:

[...] y pidiendo el libro, el padre se lo dio, pensando que lo quería besar, y él lo tomó y lo echó encima de su gente. Y el muchacho, que era la lengua, que allí estaba diciéndole aquellas cosas, fue corriendo luego y tomó el libro y diolo al padre; y el padre se volvió luego dando voces, diciendo: "Salid, salid cristianos y venid a estos enemigos perros, que no quieren las cosas de Dios, que me ha echado aquel cacique en el suelo el libro de nuestra santa Ley». Y en esto hicieron las señas al artillero que soltase los tiros en medio dellos; y así soltó los dos dellos, que no pudo soltar más [...] (Salas, 1987: 103).

En realidad, se trataba de dos pequeñas piezas de artillería propias del siglo Xvi, pero cuya sorpresiva detonación causó un fuerte estrépito, desconocido para los indios, que produjo el pánico colectivo apropiado para que los caballos, que aparecieron de súbito, acabaran por desbandar a la gente de Atahualpa: «[...] los indios que iban huyendo, que eran tantos, por huir derribaron una pared de seis pies de ancho y más de quince de largo y de altura de un hombre».

El propio Francisco Pizarro se encargó de capturar a Atahualpa con sus propias manos: 
[...] salió el gobernador con la gente que tenía, y fue derecho a las andas donde estaba aquel señor. Y muchos de los de pie que llevaba se apartaron algo dél, viendo que eran muchos los indios contrarios. Y por vengarse más dellos, con la poca gente que le quedó, el gobernador llegó a sus andas, aunque no le dejaban llegar, que muchos indios tenían cortadas las manos, y con los hombros tenían las andas de su señor; aunque no les aprovechó el esfuerzo, porque todos fueron muertos y su señor preso por el gobernador (Salas, 1987: 103).

Matanzas y fe De hombres de hace (CAsi) Medio milenio. Lo que siguió fue una carnicería que duró un par de horas:

[...] y en espacio de dos horas (que no serían más de día) toda aquella gente fue desbaratada. Y en verdad no fue por nuestras fuerzas, que éramos pocos, sino por la gracia de Dios, que es mucha. Quedaron aquel día muertos en el campo, seis o siete mil indios, sin otros muchos que llevaban los brazos cortados y otras heridas. Y, aquella noche, anduvo la gente de caballo y la de pie por el pueblo, porque vimos cinco o seis mil indios en una sierra que está encima del pueblo y andovimos guardándonos dellos (Salas, 1987: 103-104).

Sometido Atahualpa, dice el narrador, pidió hablar con «algún indio de los suyos». Pizarro hizo «traer dos indios principales de los que había tomado en la batalla». El «cacique» envió con ellos este mensaje a su gente:

[...] envió a decir a la gente que quedaba que no huyesen, sino que lo viniesen a servir, pues que él no era muerto, mas estaba en poder de los cristianos, y que a él le parecía que los cristianos eran buena gente, por tanto les mandaba que los viniesen a servir. El gobernador preguntó a la lengua qué era lo que había dicho: la lengua se lo declaró todo. El gobernador dijo que más había que les decir, y haciendo una Cruz $†$ diola al cacique, diciéndole que toda su gente, así junta como apartados unos de otros, tuviese cada uno en la mano una $\dagger$ como aquella, y que los cristianos de caballo y de pie saldrían por la mañana al campo y matarían a los que hallasen sin aquella señal de la cruz $\uparrow$. Y el otro día por la mañana salieron todos al campo con mucho concierto, y hallaron muchos escua- 
drones de los indios: el delantero de todos llevaba en las manos una cruz con el grande temor que tenían (Salas, 1987: 104-105).

Verdad y ficción. Podemos, al menos, comentar un par de escenas del genocidio, altamente sugestivas. En primer lugar, deberíamos preguntarnos si los ciento cincuenta españoles habrían tenido tiempo para matar en dos horas a seis mil indios. Es decir, en promedio, más de cuarenta indios por espada. Suponiendo que no fueran siete mil, sino solo seis mil indios los muertos, tendrían que haber matado, por persona, a un indio cada tres minutos (y sin descansar). En segundo lugar, deberíamos preguntarnos sobre si la frase de Atahualpa por la cual manda a su gente «que no huyesen, $[\ldots]$ que los cristianos eran buena gente, por tanto les mandaba que los viniesen a servir» es verídica o solo verosímil. Postulamos que estos son los momentos en que los linderos de la realidad y la ficción se entrecruzan insensiblemente en el relato, en que el texto histórico se descubre literario. No en vano advierte el narrador cuando comienza a contar la toma de Cajamarca - la ciudad oscura en la que entran, donde el hielo del granizo caía sin piedad- que: "Cada uno de los cristianos decía que haría más que Roldán, porque no esperaban otro socorro sino el de Dios».

La dulce embriaguez del país del oro: Cajamarca. A partir de aquí comienza el anónimo texto sevillano a dar cuenta del incendio dorado que lo abarcaría todo. Un puñado de ciento cincuenta aventureros, «los sesenta de caballo», había capturado el soñado país del oro — escondido en los confines del mundo, detrás de los mares, a miles de leguas del humilde terruño desde donde años atrás habían partido—. Y, ahora, todo aquel país del delirio sería solo para ellos: «Recogiose mucho oro, que había en algunos toldos y derramado por los campos; asimismo, muchas ropas $^{30}$. Todo esto recogeron los negros y los indios de servicio, que los otros estaban en orden, guardando sus personas. Recogéronse cincuenta mil pesos de oro» (Salas, 1987: 105).

30 Se refiere a los riquísimos tejidos de lana de vicuña y de alpaca. Los incas, también en textilería, verdaderamente eran delicados artistas. 
Es decir, recogieron casi un cuarto de tonelada de oro ${ }^{31}$ en la primera jornada; lo hicieron cargar con «los negros y los indios de servicio». Pero con ello apenas empezaba el frenesí; Atahualpa termina por despeñarlos hacia un abismo desde donde ya no cabría el retorno:

En aquella noche y día, ya que el cacique mostraba estar contento, dijo al gobernador que bien sabía lo que ellos buscaban. El gobernador le dijo que la gente de guerra no buscaba otra cosa sino oro, para ellos y para su señor, el emperador. El cacique dijo que él les daría tanto oro como cabría en un apartado que allí estaba, hasta una raya blanca que allí estaba, que un hombre alto no allegaba a ella con un palmo, y sería de veintecinco pies de largo y quince de ancho (Salas, 1987: 105-106).

Y Francisco Pizarro luego preguntó por la plata: «Preguntó el gobernador que cuánta plata le daría. El cacique dijo que trairía diez mil indios, y que harían un cercado en medio de la plaza, y que lo henchiría todo de vasos de plata».

LA CASA DEL ORO. Un tiempo después, uno de los capitanes de Atahualpa, Chiliachima (Calcuchímac), sometido a tormento de fuego, reveló que el cacique escondía en un toldo de su real de Cajamarca un tesoro que no les había entregado: «dijo aquel capitán indio a los cristianos que en aquel pueblo de abajo, donde el cacique Atabálipa, su señor, tenía asentado su real, estaba un toldo muy grande, en el cual el cacique tenía muchos cántaros y otras diversas piezas de oro». Cuando fueron encontraron

31 El peso, usado en los días de la fundación del Perú, fue estudiado en 1941 por el eminente Manuel Moreyra y Paz Soldán («El circulante durante la conquista e iniciación del virreinato». En: Revista de la Universidad Católica, pp. 309-348), al amparo de crónicas, testimonios, leyes y otros documentos de la época. Xerez indica que un peso corresponde a un castellano (ed. 1988: 159). Y, como sabemos, el castellano equivale a unos 4,6 gramos nuestros; y también sabemos las equivalencias de las medidas de la época en Castilla (un marco $=50$ castellanos; una libra $=100$ castellanos, etc.). El botín que se recogió en el rastreo de los toldos —en el primer día - podemos calcularlo en unos 230 kilos de oro. El valor aproximado por kilo, al momento en que escribo (junio de 2018), es de $€ 35400$ y de $\$ 41740$, respectivamente. Es decir, el primer día se recogieron unos ocho millones de euros o 10 millones de dólares, en números redondos. 
tanto que luego buscaron una casa grande de Cajamarca para amontonarlo. El narrador certifica que todo lo vio directamente:

[...] el gobernador había enviado dos hombres al toldo que el capitán había dicho, y así trujeron mucho oro, que en una casa grande había en muchas partes montones de oro de diversos quilates y piezas menudas, y el gobernador hizo fundir todo el oro menudo, entre lo cual se fundieron algunos granos de oro tan grandes como castañas y otros mayores, y otros de a libra ${ }^{32}$, otros de más peso. Y esto dígolo porque yo velaba la casa del oro y los vi fundir (Salas, 1987: 113-114).

En «la Casa del Oro» de Caxamalca amontonaron para fundir toda la orfebrería que habían recogido en hombros de los «los negros y los indios de servicio». El narrador sigue describiendo el espectáculo de la casa grande henchida de oro, así: «Había más en esta casa: ochenta cántaros de oro, grandes y pequeños, y otras piezas muy grandes. Y un montón — más alto que un hombre - de aquellas planchas, que eran todas finas y de muy buen oro. Esta casa, a una parte y a otra, toda era montones de oro y plata» (Salas, 1987: 114).

En muchas ocasiones, el narrador posa su mirada en la belleza de la orfebrería (una silla o una fuente de oro, etc.). Cierta vez nos deja ver los bultos resplandecientes de «un pastor con ovejas de oro», es decir, pastoreando sus vicuñas o llamas. En otras ocasiones, solo enumera, casi agotado de tanto contar: «Trujeron ocho cántaros de oro con otros muchos vasos y otras piezas».

Noticias DE MÁS ORO. Luego, comenzaron a llegar noticias del interior, es decir, de las provincias del país del oro. El siguiente texto habla de las noticias del oro de Pachacámac, un famoso centro de adivinación prehispánico, muy cerca de la actual ciudad de Lima (la voz quechua rímac, de donde deriva Lima, significa 'el que habla'):

32 La libra equivalía a 460 gramos nuestros (o cien castellanos). Es decir, recogieron pepitas grandes de casi medio kilo de oro. 
En esos días traían algún oro, y el señor gobernador supo que había una mezquita muy rica en aquella tierra, y que en esta mezquita había tanto oro y aun más de aquello que el cacique había prometido, porque todos los caciques de aquella tierra adoraban en ella, y asimesmo el Cuzco, que allí venían a tomar sus consejos sobre lo que habían de hacer, y muchos días del año venían a un cemín ${ }^{33}$ que tenían hecho de oro, y le daban a beber unas esmeraldas molidas.

También les llegaron noticias del oro del Collao. Cierta vez, un medio hermano de Atahualpa, de la dinastía cuzqueña, les contó que en lo que hoy conocemos como la zona del lago Titicaca y del río Desaguadero había una casa toda de oro. Nuevamente, el narrador certifica lo que cuenta:

Sé que dijo el cacique que hay otros muchos indios de aquella tierra del Collao, y que hay un río muy grande en el cual hay una isla donde hay ciertas casas, y que entre ellas está una muy grande toda cubierta de oro, y las pajas hechas de oro, porque los indios nos trujeron un manojo dellas, y que las vigas y cuanto en la casa hay, todo es de oro, y que tiene el suelo empedrado con granos de oro por fundir, y que tiene dentro della mucho oro por fundir; y esto oí decir al cacique y a sus indios, que son de aquella tierra, estando presente el gobernador.

Por alguna razón, Atahualpa se había propuesto avivar más la sed de los españoles por el oro. Por eso les habló también del oro del Cuzco y de Xauxa. Le dijo a Francisco Pizarro: "Que enviase tres cristianos al Cuzco, que estos traerían mucho oro, que desguarnecerían ciertas casas que estaban chapadas con oro, y que traerían mucho oro que había en Xauxa, y que podían ir seguros pues toda la tierra era suya».

El oro Del Cuzco. Y era cierto, ya toda la tierra era suya y también su gente. El narrador cuenta cómo los tres españoles van a buscar el oro y hacen el viaje al Cuzco a la manera de Atahualpa, es decir, los indios «los llevaban en hamacas y eran muy bien servidos».

33 Nuevo tesoro lexicográfico de la lengua española (NTLLE): Cemí (Voz de las Antillas) m. Ídolo que adoraban los pueblos antillanos; según unos, representaba un dios, según otros, un diablo. 
En el camino al Cuzco, llegaron a Xauxa, allí se encontraron con Chilicuchima (Calcuchímac, para nosotros), un capitán de Atahualpa, y les dio «30 cargas de oro», y como le reclamaran, les dio cinco cargas más ${ }^{34}$; es decir, en total, un poco más de 800 kilos de oro.

Cuando arribaron al Cuzco, arribaron también al paroxismo. Quizquiz, un alto jefe guerrero de Atahualpa, les permitió que saquearan los templos del sol, donde la luz dorada relampagueaba armoniosamente en las paredes, según la hora del día. Lo hicieron con sus propias manos, porque los indios espantados del sacrilegio — según su fe— se negaban a colaborar con la destrucción. Y también saquearon otras casas donde «había tanto oro que era cosa de maravilla»; en una de ellas, encontraron una silla de oro que pesaba unos cuarenta y seis kilos de oro:

Y luego los envió a unos bohíos del sol en que ellos adoran. Estos bohíos estaban de la parte que sale el sol, chapados de oro, de unas planchas grandes, y cuanto más les venía dando la sombra del sol tenían más abajo oro en ellos. Los cristianos fueron a los bohíos y, sin ayuda ninguna de los indios (porque ellos no les querían ayudar, porque era bohío del sol, diciendo que se morirían), los cristianos determinaron, con unas barretas de cobre de desguarecer estos bohíos, y así los desguarecieron, según por su boca ellos lo dijeron. Y más desto, juntaron en el pueblo muchos cántaros de oro y los trujeron a los cristianos, que los llevasen por rescate de su señor. En todas las casas del pueblo dicen que había tanto oro que era cosa de maravilla. En otra casa entraron donde hallaron una silla de oro; esta silla era tan grande que pesaba diez o nueve mil pesos, y se podían echar dos hombres en ella.

No se detuvieron ni ante las momias de los viejos reyes incas:

En otra casa muy grande hallaron muchos cántaros de barro cubiertos con hojas de oro que pesaban mucho; no se los quisieron quebrar por no enojar a los indios. En aquella casa estaban muchas mujeres, y estaban dos

34 Es imprecisable la cantidad en kilos, por ser la carga una medida de transporte; pero se estima que cada carga eran unas dos arrobas, es decir, un aproximado de 23 kilogramos. Aquí hablamos de unos 805 kilos de oro. 
indios en manera de embalsamados, y junto con ellos estaba una mujer viva con una máxcara de oro en la cara, ventando con un aventador el polvo y las moscas, y ellos tenían en las manos un bastón muy rico de oro. La mujer no los consintió entrar dentro si no se descalzasen, y, descalzándose, fueron a ver aquellos bultos secos y les sacaron muchas piezas ricas, y no se las acabaron de sacar todas porque el cacique Atabálipa les había rogado que no se las sacasen, diciendo que aquel era su padre el Cuzquo ${ }^{35}$, y por eso no osaron sacarle más. Así cargaron su oro, que el capitán que allí estaba les dio el aparejo que pudo.

En el Cuzco, tienen que decidirse por dejar la plata guardada (ya con autoridades indias puestas por ellos), pues ya no les es humanamente posible vigilar bien las cargas de oro que iban a transportar los indios en su espléndida caravana de guanacos y llamas, de regreso a Cajamarca:

Los cristianos hallaron en aquel pueblo tanta plata que dijeron al gobernador que había allí una casa grande cuasi llena de cántaros y tinajas grandes y vasos y otras piezas muchas, y que mucho más trujeran si no por no se detener allí más y porque estaban solos y más de doscientas leguas de los otros cristianos. Cerrada la casa y las puertas della, y puesto un sello por su majestad y por el gobernador Francisco Pizarro, y asimismo dejaron guarda de indios y pusieron señor en el pueblo, que así les era mandado.

Fue así que emprendieron el regreso: «Y tomaron su camino con el oro en que traían piezas muy hermosas, entre las cuales había una fuente muy grande, de oro muy fino, hecha de muchas piezas; pesaba esta pieza más de doce mil pesos [...]». Es decir, una fuente de más de cincuenta y cinco kilos de oro finísimo...

El arribo a Cajamarca fue espectacular: «Entraron por el real del gobernador con más de ciento y noventa indios cargados de oro; traían veinte cántaros y otras piezas grandes, que había pieza que la traían doce

35 Se refiere a Huayna Cápac. El narrador está en una etapa original en la que todavía no están precisados estos nombres incas. De hecho, nunca menciona la palabra inca. 
indios. Asimesmo trujeron otras piezas que sacaron de las casas. De plata, poca trujeron, porque así se lo mandó el gobernador, que no trujesen plata, sino oro».

En pos del oro de Pachacámac (un santuario mayor que Roma). En su imaginario, los españoles traían las mezquitas moras, pues, como sabemos, los árabes habían estado en la península ibérica por casi ocho siglos, y recién se fueron expulsados por los reyes católicos en 1492. Por esta razón, insisten en llamar mezquitas al templo de Pachacámac y a los otros templos del Sol.

Hernando Pizarro pidió licencia a su hermano para ir en busca del santuario mayor de la mar del Sur. No es menos sugestiva la narración del recojo del oro en Pachacámac: Primero, el artista nos sitúa en el camino de la «mezquita» de Pachacámac — por donde iba Hernando Pizarro- para contarnos que cuando se les gastaron las herraduras a los caballos, «el señor Hernando Pizarro mandó hacer a los indios herraduras de oro y plata y clavos, y así llevaron sus caballos al pueblo donde la mezquita estaba, el cual pueblo es mayor que Roma».

Y, aunque los indios habían escondido el oro de las ofrendas, aun así consiguen unos cuarenta mil pesos, es decir, unos 184 kilos de oro, de lo que quedaba en el templo «que lo tenían por ahí echado»; pero también de las momias insepultas y, también, de unos caciques de Chincha colaboradores: «En la mesma casa, unas indias que la guardaban, le dieron [a Hernando Pizarro] un poco de oro que lo tenían por ahí echado. Asimesmo, sacaron a los cristianos, de unos muertos que estaban allí, mucho oro, y unos caciques de Chincha le dieron oro, de manera que le dieron en todo cuarenta mil pesos».

Primera disputa entre eSPaÑoles POR el ORO. Más oro habían recibido en Guamachuco, camino de Pachacámac, el pueblo donde Atahualpa había derrotado a su hermano Huáscar. Allí se juntaba ahora el oro del rescate. El narrador nos cuenta, muy temprano, cómo dos españoles, a quienes se les habían encomendado transportar unos 460 kilos de oro, se acuchillaron por unas piezas de oro faltantes: 
Llegó el señor Hernando Pizarro a un pueblo que se decía Guamachuco, y allí halló oro que traían por rescate del cacique, que serían cien mil castellanos $^{36}$. Allí escribió Hernando Pizarro al gobernador que enviase por aquel oro, porque fuese a buen recaudo. El gobernador envió tres de caballo que viniesen con ello, y en llegando, les entregó el oro y se pasó adelante, camino de la mezquita. Los de caballo fueron con el oro adonde el gobernador estaba, y en el camino les aconteció un desastre: que los compañeros que traían el oro riñeron sobre ciertas piezas que faltaban de oro, y el uno cortó un brazo al otro [...].

El reparto del oro. Para el rey Carlos V, Pizarro le envió con su hermano Hernando un presente de cien mil pesos, algo menos de media tonelada de oro $^{37}$, «en ciertas piezas que fueron quince cántaros y cuatro ollas, que cabrían a dos arrobas de agua y otras muchas piezas menudas que eran muy ricas».

A los que estuvieron en Cajamarca «de a pie» se les dio «cuatro mil y ochocientos pesos de oro; y los de caballo al doble»: redondeando cifras, un millón de dólares para los de a pie y dos millones de dólares para los de a caballo, al cambio actual ${ }^{38}$.

A los que no estuvieron en la captura de Atahualpa, es decir, para toda «la gente que había venido con Diego de Almagro» se les dio «del oro de la compañía, antes que se repartiese, veinte y cinco mil pesos»; y a los 10 hombres que se quedaron en San Miguel de Tangarará, se les «dio dos mil pesos de oro, que los partiesen a doscientos cada uno». Ciertamente, la gente de Almagro se perdió Cajamarca: recibieron una migaja.

Y también se les repartió a los mercaderes que habían venido con el capitán Almagro «dos y a tres copones de oro, porque a todos cupiese parte».

\footnotetext{
36460 kilos de oro.

37 Xerez, secretario de Pizarro, dice que fueron 262259 pesos, es decir, más de una tonelada de oro (1 206,39 kilos). Manuel Moreyra y Paz Soldán hace cálculos más finos y, descontando gastos como los de la fundición y el quilataje, dice que fueron 261328 pesos ( $O p$. cit., p. 328).

3822,08 kilos de oro ( $€ 775639,70$ o $\$ 969549,58$, al precio actual del oro) y 44,16 kilos de oro para los de a caballo, respectivamente. Xerez da cantidades de oro parecidas.
} 
Permisos de viaje. Por diversos motivos, muchos quisieron volverse a España. Francisco Pizarro les dio permiso: «Luego hubo muchos que pidieron licencia al señor gobernador para venirse a Castilla, los unos por dar relación a Su Majestad de la tierra, otros por venir a ver a sus padres o mujeres. Dio licencia a veinte y cinco compañeros que se viniesen».

Descontentos con el reparto. La codicia ya había prendido. Los que estuvieron en la captura de Atahualpa no entendían cómo Francisco Pizarro regalara el oro a los que no habían estado en aquel histórico atardecer; es decir, se molestaron porque Pizarro compartió lo ganado con la gente de Almagro que había llegado después: «Y a muchos de los que los ganaron dio menos de lo que merecían, y esto digo porque así lo hicieron conmigo». Es decir, el propio narrador es uno de los quejosos.

Otro motivo de discordia fue que el oro continuaba llegando incesantemente de las provincias, pero Francisco Pizarro fue aconsejado de no incluir en el reparto a los que habían decidido volverse a España (entre ellos el anónimo autor de nuestro relato): «Y aconsejaron al señor gobernador que no lo hiciese venir aquel oro, porque aquellos que veniesen a Castilla no hobiesen parte. Desto no me despido de haber mi parte, pues lo ayudé a ganar». El narrador deja constancia, pues, de que intentará el resarcimiento.

Finalmente, el anónimo narrador denuncia que tampoco al rey se le está entregando completa su parte (el quinto real): «vi pesar y quedar allá, del quinto de su majestad, sin lo que llevó el señor Fernando Pizarro, más de ciento y ochenta mil pesos». Es decir, al rey se llevó — según el desconocido escritor- solo algo más de la tercera parte de lo que le correspondía. Esta grave denuncia nos da también una buena razón del anonimato de la publicación sevillana.

esCribe el final Desde España. El enunciador, es decir, el gestor del discurso que nos cuenta el relato (el enunciado enunciado), deja ver, al final, que habla desde España. Hay notorios embragues enunciativos actoriales $^{39}$, o retornos a la instancia de la enunciación, que indican la

39 Courtés, p. 370. 
posición espacial del enunciador cuando escribe: «Porque aquellos que se venían a Castilla no hobiesen parte», dice al quejarse del reparto del oro. En otro momento, cuando denuncia que el quinto del rey ha sido mermado en Cajamarca dice: «Mas digo, que vi pesar y quedar allá, del quinto de Su Majestad, sin lo que llevó el señor Fernando Pizarro, más de ciento y ochenta mil pesos». O, en otro lugar: «Yo digo que vi quedar allá, después de la partición del oro, una caja grande llena de vasos de oro y otras muchas piezas».

Justo es decir que estos embragues están al final del relato, por lo que bien pudo ser empezado en el Perú o en el barco de retorno.

«PORQUe YO LO VI»: Estos embragues enunciativos actoriales dan cuenta también de la posición temporal del enunciatario del relato ${ }^{40}$. En efecto, la memoria inquietante del pasado reciente se hace patente cuando cuenta el rito de los cráneos. Nos dice que el Cuzco (Huáscar) había prometido beber chicha en el cráneo de Atabálipa (Atahualpa), pero como el vencedor fue su medio hermano, su deseo le salió al revés: Atahualpa terminó bebiendo en la calavera del inca vencido:

El mesmo Atabálipa pensaba ser señor porque había conquistado la tierra, pocos días antes [de la llegada de los españoles], en una provincia que se dice Gomachuco, había muerto mucha gente y había prendido a un hermano suyo, el cual había jurado de beber con la cabeza del mesmo Atabálipa, y el Atabálipa bebía con la suya, porque yo lo vi, y todos los que se hallaron con el señor Hernando Pizarro, y él vio la cabeza con su cuero y las carnes secas y sus cabellos, y tiene los dientes cerrados, y allí tiene un cañuto de plata, y encima de la cabeza tiene un copón de oro pegado, por donde bebía Atabálipa cuando se le acordaba de las guerras que su hermano le había hecho, y echaban la chicha en aquel copón, y salíale por la boca y por el cañuto por donde bebía.

Estos momentos en los que el narrador retorna a la instancia de la enunciación para hacer sobresalir su presencia en el relato con un

40 Loc. at. 
rotundo: «yo lo vi» son los que le dan al texto aquel vívido encanto narrativo que atrapa al lector en la escena. Cuando cuenta la infausta fundición de los objetos de oro dice: «Y esto dígolo porque yo velaba la casa del oro, y los vi fundir».

«PoRQue YO LO OÍ»: Un procedimiento similar es el que se da cuando afirma o niega la audición de un hecho. Cuando Pizarro, luego de la ejecución de Atahualpa, unge como inca «al hijo mayor del Cuzco Viejo» (es decir, de Huayna Cápac), y dispone que se retenga la entrada del oro a Cajamarca («y esto se hacía porque no hobiesen parte los que se iban a Castilla»), el discurso retorna a la instancia de la enunciación. El enunciador se corporiza y se le atiende en su ser real (lo cual es, también una ilusión literaria). Hay sendos embragues ${ }^{41}$ o retornos a la instancia de la enunciación, donde el narrador aparece con absoluta precisión: «Otros muchos y yo oímos decir al cacique que no hiciesen volver aquel oro atrás, porque él esperaba mucho más que le habían de traer más de doscientos indios».

Cuando cuenta que, en una isla de un río del Collao, hay una casa «muy grande, toda cubierta de oro, y las pajas hechas de oro», retorna nuevamente a la instancia de la enunciación y se hace presente de modo indubitable: "Y esto oí decir al Cacique y a sus indios». Y cuando cuenta cómo se extraen las piedras de oro de aquel río maravilloso «no en bateas», sino prácticamente con las manos, el embrague semiótico es clarísimo: «Y esto yo lo oí muchas veces».

El NARRADOR FICCIONAL Y LOS DISCURSOS DE LA FICCIÓN. El relato está poblado de discursos referidos, en los cuales el narrador reproduce lo que dicen los personajes. Proponemos como ejemplo el diálogo entre el «cacique» Atahualpa y el «capitán» Chiliachima (para nosotros, Calcuchímac), cuando este quería revelar a los conquistadores dónde estaba el oro del Cuzco (es decir, de Huáscar), a quien el guerrero quiteño había vencido en «Gomachuco» (para nosotros, Huamachuco):

41 Courtés, p. 369. 
El capitán le dijo que quería decir la verdad a los cristianos, porque si no la dijese lo quemarían. Atabálipa le dijo que no dijese nada, que aquello que hacían no era sino para le poner espanto, que no osarían quemarle. Y así le preguntaron otra vez por el oro, y no lo quiso decir, mas luego que le pusieron un poco de fuego dijo que le quitasen aquel Cacique, su señor, de delante, porque él le decía del ojo que no dijese la verdad, y así se lo quitaron de allí, y luego dijo que [...].

Pero no solo hay discursos referidos, sino que hay también discursos directos donde los personajes (ficcionales) hablan con su propia voz. En la plaza de Cajamarca, se yergue soberbio en su litera Atahualpa y reta a los extranjeros: «¿Dónde están estos cristianos. Ya están todos escondidos que no parece ninguno?». Igualmente, fray Vicente Valverde grita con voz propia: «Salid, salid cristianos y venid a estos enemigos perros, que no quieren las cosas de Dios, que me ha echado aquel cacique en el suelo el libro de nuestra santa Ley».

Todos estos discursos son ficcionales. Tan ficcionales como el narrador omnisciente que da cuenta de los referidos diálogos privados que sostienen los paladines incas, Atahualpa y Calcuchímac —en quechua, por supuesto- y que él los ofrece ya traducidos al español. El propio discurso que emplea el narrador para contar la historia es también ficcional. Al respecto, dice Genette que «el enunciador del relato, personaje, a su vez de la historia [...] es también ficticio y, por consiguiente, sus actos de habla como narrador son tan serios ficcionalmente como los demás personajes de su relato» ${ }^{42}$ (énfasis nuestro). Dicho al revés, los discursos que aparecen en el relato y las voces de los personajes son tan ficcionales como la voz del que cuenta el relato. No aceptarlo así sería aceptar que Atahualpa construye discursos en español, que el narrador disponía de un aparato de grabación de voz para la cita exacta y que, en fin, cualquier otro narrador que cuente esta historia (Xerez, por ejemplo) habría de reproducir exactamente los mismos hechos y las mismas palabras de este relato de verdades. No es un relato de verdades, es un texto literario. Sin duda, es un relato que

42 Gerard Genette. Ficción y dicción, pp. 37-38. 
parte de hechos ciertos, pero su evidente textura ficcional lo enaltece como un artefacto literario.

Prosa prerrenacentista. Son evidentes las marcas del estilo del Prerrenacimiento que ya hemos señalado para otros relatos coetáneos ${ }^{43}$. Hay evidentes recursos de la amplificatio rerum, como en el siguiente fragmento donde el narrador acumula artísticamente las armas indias por donde pasan inmutables los conquistadores:

Todo el campo donde el cacique estaba, de una parte y de otra estaba cercado de escuadrones de gente, piqueros y alabarderos y flecheros, y otro escuadrón había de indios con tiraderas y hondas, y otros con porras y mazas. Los cristianos que iban pasaron por medio dellos sin que ninguno hiciese mudanza, y llegaron donde estaba el cacique, y halláronlo que estaba asentado a la puerta de su casa, con muchas mujeres alrededor dél.

OTRAS MARCAS QUE DEJA EL NARRADOR FICCIONAL. La manipulación artística que hace el narrador al contar la historia deja huellas precisas también en el relato: el actante ficcional llamado narrador elige a cada momento lo que nos cuenta, cuándo lo cuenta y cómo lo cuenta para conseguir atrapar al lector en el mundo ilusorio que le está construyendo para su deleite. Así, en el Anónimo sevillano el narrador ficcional interrumpe la historia del traslado del tesoro encontrado en el Cuzco para remontarse a Pachacámac y contar cómo Hernando Pizarro manda a hacer herrajes de oro y plata para los caballos de los conquistadores. En el enunciado están las marcas claras del embuste artístico: «Dejo de hablar en estos que venían por su camino y diré del señor Hernando Pizarro que iba camino de la mezquita $[\ldots] »$ (énfasis nuestro).

Cuando Hernando está en Pachacámac, el narrador vuelve a focalizar el relato en otro momento deleitoso, Calcuchímac le envía a decir que tiene mucho oro para darle: «Estando ahí, le envió Chiliachima (que

43 Coello. Los orígenes de la novela castellana en el Perú: La toma del Cuzco, pp. 211 y ss. 
era el capitán que prendió al Cuzco) diciendo que tenía mucho oro para llevar $[\ldots] »$.

Y así el narrador va trazando el itinerario ficcional por donde hace transitar al lector evitando que despierte de la maravilla: «Dejo de hablar en esto y diré de los cristianos que vinieron del Cuzco, los cuales entraron por el real del gobernador con más de ciento y noventa indios cargados de oro $[\ldots]$ ».

San Miguel de Tangarará y San Miguel de Piura: dos pueblos diferenTES. Es innegable que este texto toca instancias ficcionales y artísticas que lo colocan en el nivel del discurso literario, pero también es innegable que la historia que cuenta procede de la realidad. Muchos de los textos coloniales - este es uno de ellos - son textos artísticos que cuentan, a su modo, hechos ciertos, ocurridos: la forma de contar, de relatar, es la creación artística o literaria; la geografía, los personajes, las acciones, sin duda, tienen su asiento en la realidad.

Hecha la anterior salvedad, quiero dejar constancia de que, en el texto del Anónimo sevillano, Tangarará y Piura son dos lugares bien diferenciados. Y, por tratarse de un documento temprano (el libro se publica en abril de 1534, a poco más de un año de la toma de Cajamarca y a menos de dos años de la fundación de la primera ciudad castellana) es muy digno de tenerse en cuenta como testimonio prístino en este tema.

Existía un pueblo de indios que el narrador español — a partir de la voz indígena- escribe y llama Tangarará: «De allí atravesamos y fuimos a la ciudad de Túmbez. Allí estovimos dos o tres meses. De allí fuimos a un pueblo llamado Tangarará ${ }^{44}$, adonde hicimos una población que llamamos Sant Miguel. Allí tuvimos noticia de un gran señor llamado Atabálipa, el cual tenía guerra con su hermano mayor llamado el Cozco».

Y hay otro pueblo de indios, distante de aquel, que el narrador español — no sabemos si a partir de alguna voz indígena o si por designa-

44 Este pueblo existe aún y queda cerca de la actual ciudad de Sullana. 
ción castellana de la hueste conquistadora - escribe y llama Piura: «Así partimos [desde Tangarará] en busca deste cacique [Atahualpa], que nos amenazaba que él nos vernía a buscar, y el gobernador quiso ir a buscar a él. En un pueblo que se dice Piura, halló el gobernador a un capitán hermano suyo, a quien había enviado adelante con cuarenta de pie y de caballo $[\ldots] »$.

Queda claro que la primera ciudad fundada por los españoles, en el pueblo indígena de Tangarará, fue San Miguel de Tangarará, en las riberas del actual río Chira. En realidad, una ciudad mestiza, pues ya existía allí un pueblo llamado Tangarará. El Anónimo sevillano no señala la fecha de la fundación de la primera ciudad peruana.

Y queda claro, también, que la historia de la ciudad de San Miguel de Piura, en las riberas del actual río Piura (el Alto Piura), tiene una explicación posterior ${ }^{45}$.

45 Este sitio queda cerca de la actual ciudad de Morropón, y fue el segundo asiento de la primera ciudad fundada por los españoles, y pasó a llamarse, entonces, recién aquí, San Miguel de Piura. El traslado se hizo un par de años después de la primera fundación (Óscar Coello. «Los topónimos castellanos Cuzco y Piura en la Historia general y natural», de Gonzalo Fernández de Oviedo. En: Actas del VI Congreso Internacional de Lexicología y Lexicografía. Lima, Academia Peruana de la Lengua, 2011, pp. 204-209). 
https://doi.org/10.46744/bapl.201801.002

\section{BIBLIOGRAFÍA}

COELlO, Ó. (2011). «Los topónimos castellanos Cuzco y Piura en la Historia general y natural de Gonzalo Fernández de Oviedo». En: "Actas del VI Congreso Internacional de Lexicología y Lexicografía». Lima: Academia Peruana de la Lengua.

. (2010). «Los comentarios del Inca y la leyenda del Perú». Boletín de la Academia Peruana de la Lengua, 50(50). Lima: Academia Peruana de la Lengua.

. (2008). Los orígenes de la novela castellana en el Perú: La Toma del Cuzco (1539). Lima: Academia Peruana de la Lengua.

COURTÉS, J. (1977). Análisis semiótico del discurso. Madrid: Gredos.

Del BUSTO DUThurburU, J. A. (2000). Pizarro. Tomo II. Lima: Petroperú.

FERNÁNDEZ DE OVIEDO Y VALDÉS, G. (1855). Historia general $y$ natural de Indias. Tercera Parte, Tomo IV, Libro XLIII, Cap. III. Edición de José Amador de los Ríos. Madrid: Real Academia de la Historia.

GARCILASO DE LA VEGA, Y. (1609). Commentarios reales. Lisboa: Pedro Crasbeeck.

GENETTE, G. (1993). Ficción y dicción. Barcelona: Lumen.

LIDA DE MALKIEL, M. R. (1950). Juan de Mena, poeta del Prerrenacimiento español. México D. F.: Fondo de Cultura Económica.

MOREYRA Y PAZ SOLDÁN, M. (1941). «El circulante durante la conquista e iniciación del virreinato». Revista de la Universidad Católica, 9(6). 
https://doi.org/10.46744/bapl.201801.002

REAL ACADEMIA ESPAÑOLA. (2018). Nuevo tesoro lexicográfico de la lengua española. Recuperado de http://buscon.rae.es/ntlle/ SrvltGUILoginNtlle.

PORRAS BARRENECHEA, R. (1944). Cedulario del Perú (siglos XVI, XVII y XVIII). Lima: Edición del Departamento de Relaciones Culturales del Ministerio de Relaciones Exteriores del Perú.

. (1937). Las relaciones primitivas de la conquista del Perú. París: Imprimeries Les Presses Modernes.

SALAS, A. M., GUÉRIN, M. A. y MOURE, J. L. (1987). Crónicas iniciales de la conquista del Perú. Buenos Aires: Plus Ultra.

SINCLAIR, J. H. (1929). The Conquest of Peru as Recorded by a Member of the Pizarro Expedition. Reproduced from the copy of the Seville edition of 1534 in the New York Public Library with a translation and annotations by [...]. New York: The New York Public Library.

XEREZ, F. de (1988). Verdadera relación de la conquista del Perú. Madrid: Historia 16. 